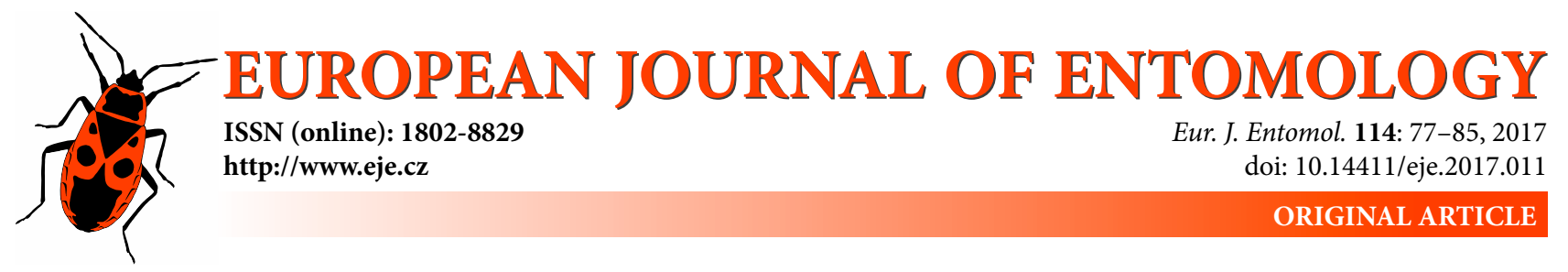

\title{
Fungi associated with Ips acuminatus (Coleoptera: Curculionidae) in Ukraine with a special emphasis on pathogenicity of ophiostomatoid species
}

\author{
Kateryna DAVYDENKO ${ }^{1,2}$, RimVYdAs VASAITIS ${ }^{2}$ and AUdrIUS MENKIS ${ }^{2}$ \\ ${ }^{1}$ Ukrainian Research Institute of Forestry \& Forest Melioration, Pushkinska st. 86, 61024 Kharkiv, Ukraine; \\ e-mail: kateryna.davydenko74@gmail.com \\ ${ }^{2}$ Department of Forest Mycology and Plant Pathology, Uppsala BioCenter, Swedish University of Agricultural Sciences, \\ P.O. Box 7026, SE-75007, Uppsala, Sweden; e-mails: rimvys.vasaitis@slu.se, audrius.menkis@slu.se
}

Key words. Coleoptera, Curculionidae, pine engraver beetle, Scots pine, Ips acuminatus, pathogens, Ophiostoma, Diplodia pinea, insect-fungus interaction

\begin{abstract}
Conifer bark beetles are well known to be associated with fungal complexes, which consist of pathogenic ophiostomatoid fungi as well as obligate saprotroph species. However, there is little information on fungi associated with Ips acuminatus in central and eastern Europe. The aim of the study was to investigate the composition of the fungal communities associated with the pine engraver beetle, I. acuminatus, in the forest-steppe zone in Ukraine and to evaluate the pathogenicity of six associated ophiostomatoid species by inoculating three-year-old Scots pine seedlings with these fungi. In total, 384 adult beetles were collected from under the bark of declining and dead Scots pine trees at two different sites. Fungal culturing from 192 beetles resulted in 447 cultures and direct sequencing of ITS rRNA from 192 beetles in 496 high-quality sequences. Identification of the above revealed that the overall fungal community was composed of 60 species. Among these, the most common were Entomocorticium sp. (24.5\%), Diplodia pinea (24.0\%), Ophiostoma ips (16.7\%), Sydowia polyspora (15.1\%), Graphilbum cf rectangulosporium (15.1\%), Ophiostoma minus (13.8\%) and Cladosporium pini-ponderosae (13.0\%). Pathogenicity tests were done using six species of ophiostomatoid fungi, which were inoculated into Scots pine seedlings. All ophiostomatoid fungi tested successfully infected seedlings of Scots pine with varying degrees of virulence. Ophiostoma minus was the only fungus that caused dieback in inoculated seedlings. It is concluded that $I$. acuminatus vectors a species-rich fungal community including pathogens such as $D$. pinea and $O$. minus. The fungal community reported in the present study is different from that reported in other regions of Europe. Pathogenicity tests showed that $O$. minus was the most virulent causing dieback in seedlings of Scots pine, while other fungi tested appeared to be only slightly pathogenic or completely non-pathogenic.
\end{abstract}

\section{INTRODUCTION}

Bark beetles (Coleoptera: Curculionidae) are among the most destructive insects in forest ecosystems and may cause huge economic losses (Ploetz et al., 2013). For example, the European spruce bark beetle, Ips typographus L. (Coleoptera: Curculionidae: Scolytinae), is capable of killing trees in large numbers, which makes it the most important and destructive bark beetle in both economic and ecological terms in coniferous forests in the palaearctic region (Christiansen \& Bakke 1988; Öhrn, 2012). A wellknown characteristic of bark beetles is their association with specific fungi, most commonly with ophiostomatoid fungi (Wingfield et al., 1993; Kirisits, 2004; Linnakoski et al., 2012), which include genera that are morphologically similar, although not phylogenetically closely related (De Beer \& Wingfield, 2013). The group includes genera such as Ophiostoma, Ceratocystiopsis, Graphilbum, Raffaelea and Leptographium in the Ophiostomatales, and Ceratocystis sensu stricto, Chalaropsis, Endoconidiophora and Graphium in the Microascales (De Beer et al., 2013, 2014). Moreover, fungi belonging to the genus Geosmithia in the Hypocreales (Ascomycota) and producing dry-spores, are also known as associates of conifer-infesting bark beetles (Kolařík \& Jankowiak, 2013; Jankowiak et al., 2014; DoriBachash et al., 2015).

The ophiostomatoid fungi include some of the bestknown tree pathogens (Kirisits, 2004), which are responsible for discolouration of wood, serious tree diseases and high rates of tree mortality (Wingfield et al., 1993; Kirisits, 2004; Linnakoski, 2011). For example, the pathogenic fungus and primary invader, Endoconidiophora polonica (Siemaszko) Z.W. de Beer, T.A. Duong \& M.J. Wingf. (previously known as Ceratocystis polonica), which can be an aggressive pathogen and kill trees (Solheim, 1988; Kirisits, 
2010), is associated with the spruce bark beetle, Ips typographus. Some bark beetles of the family Scolytinae vector the Dutch elm disease pathogens, Ophiostoma ulmi (Buisman) Nannf. and O. novo-ulmi Brasier (Menkis et al., 2016), which during the last 100 years have destroyed billions of elm trees (Ulmus spp.) worldwide (Kirisits, 2013).

Bark beetles and fungi form complex and dynamic associations, which have been shaped during long periods of co-evolution (Six \& Wingfield, 2011; Villari et al., 2013). Although a number of studies have investigated bark beetle-fungus interactions since they were first recognized in the 19th century (Harrington \& Wingfield, 1998; Six \& Wingfield, 2011; Kirisits, 2013), some interactions and beetle-fungus associations are still poorly understood (Six \& Wingfield, 2011). This can probably be explained by the fact that most previous studies mainly focused on the most economically important bark beetle species (Lieutier et al., 2009; Villari et al., 2012; Jankowiak \& Bilanski, 2013).

One such bark beetle, that is still poorly investigated, is Ips acuminatus Gyll. (Coleoptera: Curculionidae), the pine engraver beetle. This species infests the thin bark of Scots pine (Pinus sylvestris L.) throughout Europe (Villari et al., 2013). For many years I. acuminatus was considered of minor significance, however, recently I. acuminatus is reported as commonly causing extensive damage to young plantations and stands of Scots pine (Lieutier et al., 1991; Villari, 2012; Siitonen, 2014). Scots pine is among the most common and important tree species with a wide distribution in hemiboreal forests in Europe.

Several of the species of Ophiostoma associated with Ips acuminatus can cause reduction in growth, crown thinning, chlorosis or even death of trees (Colombari et al., 2012; Villari, 2012). Among the most common fungal species associated with I. acuminatus, Ophiostoma clavatum Math. is the most consistently reported (Mathiesen, 1950, 1951; Rennerfelt, 1950; Francke-Grosmann, 1952, 1963; Mathiesen-Käärik, 1953; Käärik, 1975). O. brunneo-ciliatum Math.-Käärik, although morphologically similar to O. clavatum, is reported in a few studies (Lieutier et al., 1991; Guérard et al., 2000; Villari et al., 2012) as an associate of $I$. acuminatus.

There is a general lack of information about fungi associated with I. acuminatus in central and eastern Europe as previous studies have mainly been conducted in other regions of Europe, including Sweden (Mathiesen, 1950, 1951; Mathiesen-Käärik, 1953; Käärik, 1975a, 1980), Germany (Francke-Grosmann, 1952, 1963), Finland (Linnakoski et al., 2012), Norway (Waalberg, 2015), Italy (Villari et al., 2012) and France (Lieutier et al., 1991). As damage caused by I. acuminatus is increasingly recorded (Villari, 2012; Siitonen, 2014), the investigation of fungal communities associated with $I$. acuminatus and assessment of the pathogenicity of ophiostomatoid fungi to host trees is of particular interest. Such information can be of particular practical importance for forest health, yet they have never been investigated in Ukraine, which is at the south-eastern edge of the distribution of Scots pine in Europe.
The aim of this study was to investigate the composition of fungal communities associated with the pine engraver beetle, Ips acuminatus, in the forest-steppe zone in eastern Ukraine. We also evaluated the pathogenicity of six associated ophiostomatoid by inoculating three-year-old seedlings of Scots pine with these species of fungi.

\section{MATERIALS AND METHODS}

\section{Study sites and sampling}

The sites studied were two forest stands located in the Luhansk $\left(48^{\circ} 43^{\prime} \mathrm{N}, 39^{\circ} 05^{\prime} \mathrm{E}\right)$ and Kharkiv $\left(49^{\circ} 10^{\prime} \mathrm{N}, 37^{\circ} 14^{\prime} \mathrm{E}\right)$ regions, which are in the forest-steppe zone in eastern Ukraine. Stands at both sites were ca. 50-70 year-old plantations of Scots pine. Sampling of I. acuminatus was carried out in May 2012. At each site, 192 adults of I. acuminatus were collected from stems of 38 randomly selected declining or dying trees attacked by bark beetles, resulting in a total of 384 individuals. Selected declining and dying trees were heavily defoliated due to the extensive damage caused by pine sawflies (Neodiprion serifier Geoff. and Diprion pini L., (Hymenoptera: Diprionidae) in the same season. The bark beetle entry holes were most common at the top of stems (between ca. 12 and $26 \mathrm{~m}$ from the base). The time of sampling coincided with emergence of $I$. acuminatus beetles from their galleries and their flight period. Each beetle was collected from a separate gallery; in total, between 2 and 8 individuals (5.1 on average) per tree were collected.

The trees were felled, bark was carefully removed and I. acuminatus beetles were sampled using sterilized forceps, individually placed in sterile $1.5 \mathrm{ml}$ centrifugation tubes, labelled and transported to a laboratory. Half of the beetles from each site (Luhansk and Kharkiv) were stored at $4^{\circ} \mathrm{C}$ for fungal culturing and the other half at $-20^{\circ} \mathrm{C}$ for direct DNA sequencing of fungi.

\section{Fungal isolates and molecular identification of species}

One to seven days after collection, 96 dead frozen beetles from each site (192 in total) were placed separately (without surface sterilisation and crushing) in Petri dishes containing ca. $30 \mathrm{ml}$ of Hagem agar medium supplemented with the antibiotic chloramphenicol $(0.5 \%)$ and incubated at room temperature (ca. $21^{\circ} \mathrm{C}$ ) in the dark (Persson et al., 2009). Petri dishes were checked daily for two months and outgrowing fungal mycelia were subcultured in new Petri dishes with fresh medium. Fungal cultures were divided into groups based on their morphology, and for species identification representative cultures from each group were subjected to sequencing of the internal transcribed spacer regions of the fungal ribosomal RNA (ITS rRNA). Isolation of DNA, amplification and sequencing followed the methods described by Menkis et al. (2006). Amplification by PCR was done using primers ITS1F (Gardes \& Bruns, 1993) and ITS4 (White et al., 1990). In addition, the $\beta$-tubulin gene and partial elongation factor 1-alpha (EF1-a) gene were amplified and sequenced for fungi of the genera Ophiostoma, Graphilbum and Grosmannia. The $\beta$-tubulin gene was amplified using the primers $\mathrm{Bt} 2 \mathrm{a}$ and $\mathrm{Bt} 2 \mathrm{~b}$ (Glass \& Donaldson, 1995) and the EF1-a gene the primers EF1F and EF2R following the protocols of Jacobs et al. (2004).

Each PCR reaction contained $200 \mu \mathrm{M}$ deoxyribonucleotide triphosphates, $0.2 \mu \mathrm{M}$ of each primer, $0.03 \mathrm{U} / \mu \mathrm{l}$ Thermo Green Taq polymerase with reaction buffer Green, and $2.75 \mathrm{mM}$ final concentration of $\mathrm{MgCl}_{2}$. The thermal cycling was carried out using an Applied Biosystems GeneAmp PCR System 2700 thermal cycler (Foster City, CA, USA).

For ITS primers an initial denaturation step at $95^{\circ} \mathrm{C}$ for $5 \mathrm{~min}$ was followed by 35 amplification cycles of denaturation at $95^{\circ} \mathrm{C}$ for $30 \mathrm{~s}$, annealing at $55^{\circ} \mathrm{C}$ for $30 \mathrm{~s}$, and extension at $72^{\circ} \mathrm{C}$ for 
$30 \mathrm{~s}$. The thermal cycling was ended by a final extension step at $72^{\circ} \mathrm{C}$ for $7 \mathrm{~min}$. PCR conditions for EF1-a amplification were the same as those for ITS except the annealing temperature, which was $60^{\circ} \mathrm{C}$. Thermal cycling conditions for the $\beta$-tubulin gene were $2 \mathrm{~min}$ at $95^{\circ} \mathrm{C}$ followed by 35 cycles of $95^{\circ} \mathrm{C}$ for $30 \mathrm{~s}, 58^{\circ} \mathrm{C}$ for $45 \mathrm{~s}$, and $72^{\circ} \mathrm{C}$ for $45 \mathrm{~s}$, with a final extension of $72^{\circ} \mathrm{C}$ for 5 $\min$.

PCR products were separated on $1 \%$ agarose gels and visualized under UV light. The PCR products were purified with Qiagen DNA extraction PCR M kit (Qiagen, Hilden, Germany). Sequencing was carried out by Macrogen Inc., Korea. Raw sequence data were analyzed using the SeqMan Pro version 10.0 software from DNASTAR package (DNASTAR, Madison, WI, USA). Sequences were quality-filtered and assembled into different contigs (of $\geq 98 \%$ similarity representing different fungal species), which were used for analysis. Databases at GenBank (Altschul et al., 1990) and at the Department of Forest Mycology and Plant Pathology, Swedish University of Agricultural Sciences, were used to determine the identity of ITS rRNA sequences. The criteria used for identification were: sequence coverage $>80 \%$; similarity to species level $98-100 \%$, similarity to genus level 94 97\%. All generated sequences were deposited in GenBank and accession numbers are provided in Table 1.

\section{Sequencing of fungi from the beetles}

Isolation of DNA (without surface sterilisation) from the beetles (beetles were frozen, crushed and DNA was isolated separately from each individual), amplification and sequencing of fungal ITS rRNA were carried out as described by Persson et al. (2009). Amplification by PCR was done in two steps: firstly using fungal specific primers NLC2 (GAGCTGATTCCCAAACAACTC) and NSA3 (AAACTCTGTCGTGCTGGGGATA) (Davydenko et al., 2014), and then in a second (nested) PCR using primers ITS1F and ITS4 as above. PCR products were separated on 1\% agarose gels and visualized under UV light. If only one DNA band was present on the gel per sample, following nested PCR, the PCR product was used for sequencing. Multiple-banded PCR products were separated on $2.0 \%$ agarose gels, individual bands were excised and re-amplified using the universal primers ITS 1 and ITS4 (White et al., 1990). Resulting single-band products were sequenced in both directions using the same primers as for PCR amplification. Sequencing and analysis of sequencing data were performed as described above. All generated sequences were deposited in GenBank (Table 1).

\section{Pathogenicity tests}

To investigate the effect of the ophiostomatoid fungi isolated from I. acuminatus infesting Scots pine, three-year-old seedlings of Scots pine produced in a nursery were inoculated with the fungi. Seedlings were grown outdoors in containers and watered as required. Stem diameters at the inoculation site were between $10.4 \mathrm{~mm}$ and $13.2 \mathrm{~mm}$ (12.2 $\mathrm{mm}$ on average). Six species of ophiostomatoid fungi, that were commonly cultured from I. acuminatus, were used in the pathogenicity tests: Graphilbum cf. rectangulosporium, O. ips, O. minus, O. pallidulum, O. piceae and Grosmannia olivacea. Fungi were maintained on 2\% malt-extract agar (MEA) medium and actively growing 15-day-old fungal mycelia were used for inoculation. In May 2012, 120 seedlings of Scots pine were inoculated with selected fungal species $(20$ seedlings for each species). In addition, twenty plants were inoculated with sterile $2 \%$ MEA as controls. Inoculations were done by cutting out a piece (ca. $4 \times 8 \mathrm{~mm}$ in size) of the bark on the stem ca. $40 \mathrm{~cm}$ above the root collar with a sterile scalpel, placing fungal inoculum on the exposed sapwood and covering it up with the bark and wrapping with Parafilm, as described by Krokene
\& Solheim (1998). These plants were monitored weekly for 20 weeks. A seedling was considered dead when the bark and needles above the inoculation point were discoloured and dead. After 20 weeks, all plants were harvested and the bark was removed around the inoculation site. The length of the necrotic lesion on the sapwood and the depth of blue-stain were measured to estimate the area colonized. In addition, two pieces of wood tissue ca. $1 \mathrm{~cm}$ in length from each side of the infection zone were removed and plated on Hagem agar medium containing antibiotics $(0.8 \%$ cycloheximide and $0.2 \%$ streptomycin sulphate, CSMA $)$ in order to re-isolate the inoculated fungi. In total, 280 wood pieces were used for re-isolation of fungi. Plates were stored for five weeks at $20^{\circ} \mathrm{C}$ in the dark and checked daily for growth of the inoculated fungi.

\section{Statistical analyses}

Richness of fungal species detected in beetles from trees of different health status (living vs. dead), at different sites (Luhansk vs. Kharkiv) and detected by different methods (culturing vs. sequencing) was compared using chi-squared tests (Mead \& Curnow, 1983). The relative abundance of fungal species was calculated from actual numbers of observations (presence/absence data) as a percentage of the observations (fungal cultures/ sequences) for the total fungal community. Shannon diversity indices and quantitative Sorensen similarity indices were used to characterize the diversity and composition of fungal communities (Shannon, 1948; Magurran, 1988). The Simpson diversity index (Simpson, 1949) was used to estimate the dominance in fungal diversity while taking into account both richness and evenness. Fungal dominance was determined using Camargo's index (Camargo, 1993) and dominant species are marked with "d" in the table. A species was defined as dominant if $\mathrm{Pi}>1 / \mathrm{S}$. The data from the inoculation test were analyzed using analysis of variance (ANOVA). Significant treatment differences were further evaluated by Fisher's (LSD) test in STATISTICA ${ }^{\circledR} 7.0$ (StatSoft, Inc., Tulsa, OK, USA).

\section{RESULTS}

\section{Fungi vectored by Ips acuminatus}

Of the 192 beetles of I. acuminatus used for fungal culturing, 183 individuals $(95.3 \%)$ yielded fungal cultures (Table 1). There were between one and five different fungal cultures from each beetle (2.3 on average), resulting in 447 cultures in total. The sequencing of representative fungal cultures revealed the presence of 42 distinct fungal species among which $37(88.1 \%)$ could be identified to species level, four $(9.5 \%)$ to genus level and one $(2.4 \%)$ remained unidentified (Table 1). All of the 192 beetles used for direct amplification and sequencing of the fungal ITS rRNA region resulted in successful amplification. There were between one and three fungal amplicons (2.6 on average) from each. Separation and sequencing of individual amplicons resulted in 496 high-quality sequences for 54 distinct fungal species among which 39 (72.6\%) were identified to species level, ten (18.5\%) to genus level and five $(9.2 \%)$ remained unidentified (Table 1$)$. A chi-squared test revealed no statistically significant difference in the richness of fungal species detected by culturing vs. direct sequencing $(p>0.05)$. The Sorensen index of similarity of fungal communities was high (0.59) when the results of culturing vs. direct sequencing were compared. Pooling the results from culturing and sequencing revealed 
Table 1. Frequency (\%) of fungal species cultured/directly sequenced from adults of Ips acuminatus that were collected from Pinus sylvestris growing at Luhansk and Kharkiv in eastern Ukraine.

\begin{tabular}{|c|c|c|c|c|c|c|c|c|}
\hline \multirow{2}{*}{ Fungal species } & \multirow{2}{*}{$\begin{array}{l}\text { Genbank } \\
\text { access. no. }\end{array}$} & \multicolumn{2}{|c|}{ Luhansk } & \multicolumn{4}{|c|}{ Kharkiv } & \multirow{2}{*}{-Total } \\
\hline & & quenci & ulturin & All & quenc & ulturin & g All & \\
\hline \multicolumn{9}{|l|}{ Ascomycota (ophiostomatoid species) } \\
\hline Graphilbum cf. rectangulosporium Ohtaka, Masuya \& Yamaoka ${ }^{d}$ & KU663982 & - & 11.5 & 5.7 & 13.5 & 35.4 & 24.5 & 15.1 \\
\hline Grosmannia olivacea (Math.-Käärik) Zipfel, Z.W. de Beer \& M.J. Wingf. & KU663987 & - & 3.1 & 1.6 & - & - & - & 0.8 \\
\hline Ophiostoma ips (Rumbold) Nannfeldt & KU663983 & - & 23.9 & 11.9 & 12.5 & 30.2 & 21.4 & 16.7 \\
\hline Ophiostoma minus (Hedgc.) Syd. \& P. Syd ${ }^{d}$ & KU663984 & 12.5 & 16.7 & 14.6 & 4.2 & 21.9 & 13.0 & 13.8 \\
\hline Ophiostoma pallidulum Linnak., Z.W. de Beer \& M.J. Wingf. & KU663985 & - & 7.3 & 3.7 & 2.1 & 27.1 & 14.6 & 9.1 \\
\hline $\begin{array}{l}\text { Ophiostoma piceae (Münch) Sydow \& P. Sydow } \\
\text { Other Ascomycota }\end{array}$ & KU663986 & - & 7.3 & 3.7 & - & 19.8 & 9.9 & 6.8 \\
\hline Alternaria alternata (Fries) Keissler & KU663948 & 1.0 & - & 0.5 & 8.3 & 5.2 & 6.8 & 3.7 \\
\hline Anthostomella pinea Crous & KU663949 & - & - & - & 6.3 & - & 3.1 & 1.3 \\
\hline Apiospora montagnei Sacc. & KU663950 & - & - & - & - & 9.4 & 4.7 & 2.3 \\
\hline Aspergillus pseudoglaucus Blochwitz & KU663951 & - & - & - & - & 6.3 & 3.1 & 1.6 \\
\hline Aspergillus versicolor (Vuill.) Tirab. & KU663952 & - & - & - & 2.1 & 2.1 & 2.1 & 1.1 \\
\hline Beauveria bassiana (Balsamo-Crivelli) Vuillemin & KU663953 & 2.1 & 6.3 & 4.2 & 1.0 & 3.1 & 2.1 & 3.1 \\
\hline Bionectria ochroleuca (Schwein.) Schroers \& Samuels & KU663954 & - & - & - & 5.2 & - & 2.6 & 1.3 \\
\hline Bionectriaceae sp. Samuels \& Rossman & KU663955 & - & - & - & 1.0 & - & 0.5 & 0.3 \\
\hline Chaetomium globosum Kunze ex Fries & KU663957 & - & - & - & 1.0 & - & 0.5 & 0.3 \\
\hline Chaetomium sp. Kunze & KU663958 & - & 5.2 & 2.6 & - & 14.6 & 7.3 & 4.9 \\
\hline Chalara sp. (Corda) Rabenhorst & KU663959 & - & - & - & 2.1 & - & 1.0 & 0.5 \\
\hline Cladobotryum dendroides (Bull.) W. Gams \& Hooz & KU663960 & - & - & - & 1.0 & 3.1 & 2.1 & 1.0 \\
\hline Cladobotryum mycophilum (Oudem.) W. Gams \& Hooz & KU663961 & 6.3 & 9.4 & 7.8 & - & 9.4 & 4.7 & 6.3 \\
\hline Cladosporium cladosporioides (Fresen.) G.A. de Vries & KU663962 & 4.2 & - & 2.1 & 3.1 & 2.1 & 2.6 & 2.3 \\
\hline Cladosporium pini-ponderosae K. Schub d & KU663963 & 22.9 & - & 11.5 & 17.7 & 11.5 & 14.6 & 13.1 \\
\hline Cladosporium sp. Link & KU663964 & - & - & - & 4.2 & 5.2 & 4.7 & 2.3 \\
\hline Cyclaneusma niveum (Pers.) DiCosmo, Peredo \& Minter & KU663965 & - & - & - & 3.1 & - & 1.6 & 0.8 \\
\hline $\begin{array}{l}\text { Dactylonectria macrodidyma (Halleen, Schroers \& Crous) } \\
\text { L. Lombard, van der Merwe \& J.Z. Groenew. \& Crous }\end{array}$ & KU663971 & - & - & - & 3.1 & - & 1.6 & 0.8 \\
\hline Gibberella avenacea R.J. Cook & KU663968 & 2.08 & 1.1 & 1.6 & - & - & - & 0.8 \\
\hline Isaria farinosa (Holmskjold) Fries & KU663972 & - & 2.1 & 1.1 & 1.1 & 15.6 & 8.3 & 4.7 \\
\hline Lophodermium seditiosum Minter, Staley \& Millar & KU663973 & 2.08 & - & 1.1 & - & 5.2 & 2.6 & 1.8 \\
\hline Mariannaea elegans (Corda) Samson & KU663974 & - & 6.3 & 3.1 & 2.1 & 3.1 & 2.6 & 2.9 \\
\hline Metapochonia bulbilosa (W. Gams \& Malla) Kepler, Rehner \& Humbe & KU663975 & - & - & - & 1.1 & 2.1 & 1.6 & 0.8 \\
\hline Nakazawaea holstii (Wick.) Y. Yamada, K. Maeda \& Mikata & KU663978 & - & - & - & 4.2 & 8.3 & 6.3 & 3.1 \\
\hline Neocatenulostroma germanicum (Crous \& U. Braun) Quaedvl. \& Crous & s KU663979 & - & - & - & 2.1 & - & 1.1 & 0.5 \\
\hline Ogataea henricii (Wick.) Y. Yamada, K. Maeda \& Mikata & KU663981 & 6.3 & - & 3.1 & 7.3 & - & 3.7 & 3.4 \\
\hline Ogataea neopini Nagatsuka, S. Saito \& Sugiyama & KU663980 & - & - & - & 7.3 & - & 3.7 & 1.8 \\
\hline Penicillium citreonigrum Dierckx & KU663988 & 4.2 & - & 2.1 & 1.1 & 3.1 & 2.1 & 2.1 \\
\hline Penicillium roqueforti Thom & KU663990 & 4.2 & - & 2.1 & - & 7.3 & 3.4 & 2.9 \\
\hline Pezicula eucrita (P. Karst.) P. Karst & KU663991 & 2.1 & - & 1.1 & - & 5.2 & 2.7 & 1.8 \\
\hline Phoma macrostoma Montagne & KU663993 & - & - & - & 1.1 & 2.1 & 1.6 & 0.8 \\
\hline Phomopsis sp. Sacc. \& Roum & KU663994 & 6.3 & - & 3.1 & 6.3 & 3.1 & 4.7 & 3.9 \\
\hline Pleosporales sp. & KU663989 & 2.1 & - & 1.1 & 2.1 & - & 1.1 & 1.1 \\
\hline Rhizoctonia sp. DC & KU663995 & - & - & - & 5.21 & - & 2.60 & 1.30 \\
\hline Diplodia pinea (Fr.) Dyko \& B. Sutton ${ }^{d}$ & KU663996 & 39.6 & 14.6 & 27.1 & 28.1 & 13.5 & 20.8 & 23.9 \\
\hline Sydowia polyspora (Brefeld \& Tavel) E. Müller & KU663997 & 16.7 & 1.1 & 8.9 & 19.8 & 22.9 & 21.4 & 15.1 \\
\hline $\begin{array}{l}\text { Talaromyces minioluteus (Dierckx) Samson, N. Yilmaz, } \\
\text { Frisvad \& Seifert }\end{array}$ & KU663998 & 2.1 & - & 1.1 & - & 3.1 & 1.6 & 1.3 \\
\hline $\begin{array}{l}\text { Talaromyces purpureogenus Samson, Yilmaz, Houbraken, } \\
\text { Spierenb., Seifert, Peterson, Varga \& Frisvad }\end{array}$ & KU663999 & - & - & - & 1.1 & 7.3 & 4.2 & 2.1 \\
\hline Trichoderma asperellum Samuels, Lieckfeldt \& Nirenberg & KU664000 & 4.2 & - & 2.1 & - & 2.1 & 1.1 & 1.6 \\
\hline Truncatella sp. Steyaert & KU664001 & - & 1.1 & 0.5 & 3.1 & 5.2 & 4.2 & 2.3 \\
\hline Unidentified Ascomycota175244 & KU664003 & 8.3 & - & 4.2 & 20.8 & - & 10.4 & 7.3 \\
\hline Unidentified Helotiales HH79 & KC768103 & - & - & - & 3.1 & - & 1.6 & 0.8 \\
\hline $\begin{array}{l}\text { Unidentified Pezizales } \\
\text { Basidiomycota }\end{array}$ & KU664004 & - & - & - & 3.1 & - & 1.6 & 0.8 \\
\hline Bjerkandera adusta (Willdenow) P. Karsten & KU663956 & 2.1 & - & 1.1 & 3.1 & 2.1 & 2.6 & 1.8 \\
\hline Entomocorticium sp. H.S. Whitney, Bandoni \& Oberw ${ }^{d}$ & KU663966 & 62.5 & - & 31.3 & 35.4 & - & 17.7 & 24.5 \\
\hline Fomitopsis pinicola (Swartz) P. Karsten & KU663967 & 14.6 & - & 7.3 & 11.5 & 5.2 & 8.3 & 7.8 \\
\hline Hebeloma sp. (Fr.) P. Kumm. & KU663969 & 6.3 & - & 3.1 & - & 7.3 & 3.7 & 3.4 \\
\hline Hyphoderma setigerum (Fr.) Donk & KU663970 & - & - & - & 7.3 & 9.4 & 8.3 & 4.2 \\
\hline Phlebiopsis gigantea (Fr.) Jülich & KU663992 & 4.2 & - & 2.1 & - & 3.1 & 1.6 & 1.8 \\
\hline $\begin{array}{l}\text { Unidentified Basidiomycota FG139 } \\
\text { Mucoromycotina }\end{array}$ & KU664005 & - & - & - & 1.1 & 4.2 & 2.6 & 1.3 \\
\hline Mucor sp. P. Micheli ex L. & KU663977 & 2.1 & - & 1.1 & - & - & - & 0.5 \\
\hline Mucor fragilis Bainier & KU663976 & - & - & - & - & 6.3 & 3.1 & 1.6 \\
\hline Umbelopsis isabellina (Oudemans) W. Gams & KU664002 & - & - & - & 5.2 & - & 2.6 & 1.3 \\
\hline Unidentified culture Mucor-like & & - & - & - & 5.2 & - & 2.6 & 1.3 \\
\hline Total & & 24.3 & 11.8 & 36 & 28.3 & 35.6 & 63.9 & 100 \\
\hline No. of species & & 25 & 15 & 35 & 43 & 39 & 56 & 60 \\
\hline Shannon-Weaver diversity index & & 2.6 & 2.4 & 2.9 & 3.2 & 3.3 & 3.6 & 3.5 \\
\hline Simpson diversity index & & 0.11 & 0.1 & 0.1 & 0.1 & 0.04 & 0.03 & 0.04 \\
\hline
\end{tabular}

Dominant species are marked with "d" in Table 1. 
that there were 35 different fungal species recorded for Luhansk and 56 for Kharkiv (chi-square test, difference significant at $\mathrm{p}<0.0001)$ (Table 1$)$. Thirty five $(58.3 \%)$ fungal species were common to both sites. As a result, the Sorensen index of similarity of fungal communities was 0.37 between the sites (Luhansk and Kharkiv). For different datasets (detected by different methods and at different sites), the Shannon diversity index varied between 2.4 and 3.59, while the Simpson diversity index was between 0.03 and 0.11 (Table 1).

The overall fungal community (detected by both methods and at both sites) was composed of $80 \%$ Ascomycota, $11.7 \%$ Basidiomycota and $8.3 \%$ Mucoromycotina. The most commonly detected fungi were Entomocorticium sp. (24.5\%), Diplodia pinea (24.0\%), Ophiostoma ips (16.7\%), Sydowia polyspora (15.1\%), G. cf. rectangulosporium (15.1\%), Ophiostoma minus (13.8\%) and Cladosporium pini-ponderosae $(13.0 \%)$. The relative abundance of each of the remaining fungal species was lower than $10 \%$ (Table 1). Six ophiostomatoid fungi were detected and their identity confirmed using ITS rRNA, EF1-a and $\beta$-tubulin sequencing. Ophiostoma ips was the most common ophiostomatoid fungus (Table 1). While $G$. cf. rectangulosporium and $O$. minus were relatively highly abundant, O. pallidulum, $O$. piceae and in particular $G$. olivaceum were less common $(9.11 \%, 6.8 \%$ and $0.78 \%$, respectively) (Table 1). Interestingly, O. pallidulum was relatively common at Luhansk, while G. olivaceum was found only at Kharkiv (Table 1). Entomocorticium sp. was the most common species at both sites, where it was detected only by direct DNA sequencing. However, the number of beetles with an association with Entomocorticium sp. at Luhansk was almost twice as high as at Kharkiv.

A non-ophiostomatoid species, Diplodia pinea (Fr.) Dyko \& B. Sutton, was also frequently detected with a $28.1 \%$ abundance at Kharkiv and $24.0 \%$ at Luhansk (Table 1).

\section{Pathogenicity tests}

Inoculation with the six ophiostomatoid fungi commonly resulted in the formation of necrotic wounds and resin flow from the stem, and revealed that the virulence and colonization patterns of the tissues of the different fungal species differed (Table 2). While only $O$. minus caused the death of the inoculated seedlings, both $O$. minus and $G$. cf. rectangulosporium caused seedling decline (Table 2). Dead and declining seedlings showed symptoms of stem necro- sis, and discolouration and loss of needles. No dieback or decline was recorded in the control seedlings.

All inoculated fungi were able to infect plant tissues and cause lesions of different sizes (Table 2). With the exception of G. olivacea, all fungi caused dark-brown lesions. The lesions were generally covered with resin and extended vertically in both directions from the point of inoculation. $O$. minus caused significantly larger necrotic lesions than $G$. cf. rectangulosporium $(\mathrm{p}<0.05)$ and both caused significantly larger necrotic lesions than $O$. ips, O. pallidulum and $O$. piceae, which caused similar sized lesions. In contrast to the other species, the size of the lesions caused by $G$. olivacea did not differ significantly from those of controls (Table 2). The inoculated fungi were successfully re-isolated from $70-100 \%$ of the plants (Table 2 ).

\section{DISCUSSION}

\section{Fungal community}

The results demonstrate that I. acuminatus in the Ukraine is associated with a species rich community of fungi, which includes 39 different genera and 60 different species (Table 1). This study also revealed site-specific differences in the fungal communities with that recorded at Kharkiv significantly more species-rich than that at Lugansk (Table 1). Difference between the fungal communities at Kharkiv and Luhansk may be due to differences in microclimate conditions at these two sites. For example, higher temperatures (even up to $45^{\circ} \mathrm{C}$ ) throughout the vegetative season in the last decades and lower levels of precipitation at Luhansk than at Kharkiv might account for the lower abundance of fungi at Luhansk. Moreover, temperature fluctuations during the vegetative season can limit dispersal of some ophiostomatoid and other symbiotic fungi, which have lower range of optimal temperatures (Six \& Bentz, 2007).

As mentioned above, the Sorensen index of similarity of the fungal communities was high (0.59) when comparing culturing vs. direct sequencing. Similarly, there was no significant difference between Shannon's diversity index ( $p$ $=0.02$ ) among the fungal identification methods. Despite this, there were some significant differences in the fungal species detected using only one of these methods. Grosmannia olivacea was only found using the isolation method whereas Entomocorticium sp., several yeasts and other fungal species only by direct sequencing. Moreover, a recently discovered phytopathogen in Ukraine Neocatenulostroma germanicum (Markovskaja et al., 2016) was also

Table 2. Effect of inoculation of three-year-old Pinus sylvestris seedlings with ophiostomatoid fungi associated with Ips acuminatus. Values for the depth to which the blue-stain extended and lesion length are means \pm one standard error.

\begin{tabular}{|c|c|c|c|c|c|c|c|}
\hline Fungal species & Strain & $\begin{array}{l}\text { Origin } \\
\text { of strains }\end{array}$ & $\begin{array}{l}\text { Depth } \\
\text { of blue-stain }(\mathrm{mm})\end{array}$ & $\begin{array}{l}\text { Length of the } \\
\text { lesion (mm) }\end{array}$ & $\begin{array}{c}\text { Dead plants } \\
(\%)\end{array}$ & $\begin{array}{c}\text { Declining plants } \\
(\%)\end{array}$ & $\begin{array}{l}\text { Re-isolation } \\
\text { success (\%) }\end{array}$ \\
\hline G. cf rectangulosporium & AB41 & Kharkiv & $1.3 \pm 0.12^{d}$ & $11.6 \pm 0.2^{c}$ & $0^{a}$ & $10^{c}$ & 95 \\
\hline G. olivacea & AK77 & Luhansk & $0^{\mathrm{a}}$ & $0.9 \pm 0.1^{a}$ & $0^{\mathrm{a}}$ & $0^{a}$ & 70 \\
\hline O. ips & AK188 & Kharkiv & $0.2 \pm 0.04^{b}$ & $3.9 \pm 0.4^{b}$ & $0^{a}$ & $0^{\mathrm{a}}$ & 100 \\
\hline O. minus & AB14 & Kharkiv & $1.6 \pm 0.11^{c}$ & $19.6 \pm 0.9^{d}$ & $45^{b}$ & $25^{b}$ & 100 \\
\hline O. pallidulum & AK127 & Kharkiv & $0.2 \pm 0.4^{b}$ & $2.9 \pm 0.2^{b}$ & $0^{\mathrm{a}}$ & $0^{\mathrm{a}}$ & 80 \\
\hline O. piceae & AN1 & Kharkiv & $0.2 \pm 0.03^{b}$ & $3.2 \pm 0.1^{\mathrm{b}}$ & $0^{\mathrm{a}}$ & $0^{\mathrm{a}}$ & 85 \\
\hline Control & & & $0^{a}$ & $0^{a}$ & $0^{a}$ & $0^{a}$ & 0 \\
\hline
\end{tabular}

Within columns, values followed by the same letter are not significantly different at $p=0$. 
found by direct sequencing. The latter demonstrates that the use of the two different detection methods provided complementary information about the fungal communities associated with I. acuminatus in Ukraine.

The present study, as well as providing new information for the south-eastern part of the Scots pine distribution in Europe, corroborates previous studies (Kirisits, 2004; Linnakoski et al., 2010) that fungi of the genera Ophiostoma, Graphilbum and Grosmannia are among the most common symbionts of bark beetles (Table 1).

Despite their common occurrence, the richness of species of Ophiostoma was relatively low and included only $O$. ips, G. cf. rectangulosporium, O. minus, O. pallidulum, O. piceae and G. olivacea (Table 1). Among these, O. minus is one of the most well studied and widespread ophiostomatoid fungi commonly associated with different species of bark beetle and pine-infesting weevils (Kirisits, 2004; Jankowiak, 2013). However, there are only three reports of it's association with I. acuminatus: Sweden (Mathiesen-Käärik, 1960), Finland (Linnakoski et al., 2012) and Norway (Waalberg, 2015). In the present study, $G$. cf. rectangulosporium was commonly associated with I. acuminatus. This fungus was also isolated earlier in Ukraine from Hylurgus ligniperda Fabricius (Coleoptera: Curculionidae) (Davydenko et al., 2014). Previous studies in Poland and Spain show that G. rectangulosporium is associated with weevils and bark beetles (Romon et al., 2007; Jankowiak \& Kolařík 2010; Jankowiak \& Bilański 2013). Moreover, in 2006 G. rectangulosporium was also described from Japan in association with the bark beetle infesting Abies spp. (Ohtaka et al., 2006) and in 2009 from China in association with Dendroctonus valens Le Conte (Coleoptera: Curculionidae) infesting Pinus tabuliformis Carr. (Lu et al., 2009).

Ophiostoma ips has a worldwide distribution and is associated with a number of different bark beetles (Kim et al., 2003, Zhou et al., 2007). In the present study, O. ips was isolated from I. acuminatus collected at both sites. Earlier reports indicate this fungus occurs at a low frequency in association with $H$. lignipeda in Ukraine (Davydenko et al., 2014) and is also found in Sweden (Mathiesen-Käärik, 1953), Finland (Linnakoski et al., 2012) and Norway (Waalberg, 2015).

Surprisingly, both $O$. brunneo-ciliatum and $O$. clavatum (or $O$. clavatum species complex), which are commonly associated with I. acuminatus in Italy (Villari et al., 2013) and Sweden (Mathiesen-Käärik, 1953, 1960), were not detected. A recent publication (Linnakoski et al., 2016) confirms that $O$. clavatum is closely associated with $I$. acuminatus, while $O$. brunneo-ciliatum appears to be mainly associated with another beetle, Ips sexdentatus. It is possible that high temperatures and low humidity during the vegetative period has limited the spread of these species into eastern Ukraine (Six \& Bentz, 2007). In contrast, our results show that the ophiostomatoid community associated with $I$. acuminatus in Ukraine is similar to that of Ips sexdentatus (Börner), (Coleoptera: Curculionidae) in Poland (Jankowiak, 2012).
Interestingly, a mycangial fungus Entomocorticium sp., which was the most commonly detected fungus in the present study, has previously only been reported in association with Dendroctonus ponderosa Hopkins (Coleoptera: Curculionidae) (Whitney et al., 1987) and Dendroctonus frontalis Zimmermann (Coleoptera: Curculionidae) (Klepzig et al., 2004). Entomocorticium sp. may provide nutritional benefits to larvae of bark beetles, whereas $O$. minus results in poorly developed larvae, which often fail to reach the adult stage (Klepzig et al., 2004; Six, 2012). Entomocorticium sp. may provide some protection for larvae of bark beetles against the negative effect of $O$. minus (Kirisits, 2007). In contrast, Ambrosiella macrospora (FrankeGrosm.), which is primarily a food source for larvae and thought to be non-pathogenic, is commonly associated with I. acuminatus in Italy (Villari et al., 2012), but was not detected in the present study. The latter examples demonstrate that I. acuminatus may vector rather different fungal communities in different parts of Europe.

Diplodia pinea is a widely distributed pathogen of conifers causing Diplodia tip blight and stem canker disease (Oliva et al., 2013). Previously, associations between D. pinea and Tomicus piniperda L. (Coleoptera: Curculionidae), Hylastes attenuatus Erichson, (Coleoptera: Curculionidae), Hylurgops palliates (Gyll.) (Coleoptera: Curculionidae), and Xyleborus dispar (F.) (Coleoptera: Curculionidae) beetles were reported from northern Spain (Goldazarena et al., 2012). Also, a possible interaction between the exotic insect Leptoglossus occidentalis Heidemann (Hemiptera: Coreidae) and D. pinea is postulated because both these species damage pine cones in Italy (Luchi et al., 2012). Moreover, D. pinea is effectively vectored by Hylastes ater (Paykull) (Coleoptera: Curculionidae), Hylastes opacus Erichson (Coleoptera: Curculionidae) and H. ligniperda in Poland (Jankowiak \& Bilański, 2013). The present study, therefore, provides evidence, for the first time, that $D$. pinea is commonly associated with $I$. acuminatus in Ukraine. As disease symptoms caused by $D$. pinea were often observed on Scots pine at the time of sampling, the possibility should not be excluded that in addition to the negative effect of I. acuminatus and ophiostomatoid fungi, $D$. pinea has also contributed to the decline and dieback of Scots pine, however this requires more specific investigation.

Interestingly, Geosmithia spp. are not detected in many studies on the fungal species associated with I. acuminatus. Anamorphic fungi of the genus Geosmithia (Ascomycota: Hypocreales) are associated with 33 species of bark beetles (Kolařík et al., 2008; Kolařík \& Jankowiak, 2013). However, most isolations of species of Geosmithia are from bark beetle galleries (Jankowiak, 2006; Kolařík et al., 2008). All seven species of Geosmithia principally inhabit bark beetle galleries, but are rarely in insect-free wood (Kolařík et al., 2008).

\section{Pathogenicity test}

All the ophiostomatoid fungi tested infected seedlings of Scots pine with varying degrees of virulence. The pathogenicity results were generally consistent with pre- 
viously described inoculation experiments, with similar lesion morphology and patterns of plant tissue colonization by different ophiostomatoid species (Krokene \& Solheim, 1998; Solheim \& Krokene, 1998; Jankowiak, 2013). Ophiostoma minus caused dieback in Scots pine seedlings thereby confirming the results of previous studies (Jankowiak, 2006, 2013). In addition, following mass inoculation, O. minus also kills large Scots pine trees (Långstrom et al., 1993; Solheim et al., 1993, 2001). In dead and declining seedlings, $O$. minus colonized sapwood and produced a substantial blue-stain in the area of the inoculation. The ability to invade sapwood and phloem are considered critical for the pathogenic colonization (Krokene \& Solheim, 1998). O. minus is the most aggressive pathogen of Scots pine seedlings and may also affect large trees; however, this remains to be quantitatively tested (Långstrom et al., 1993; Solheim et al., 1993, 2001). In addition to O. minus, $G$. cf. rectangulosporium caused the decline of Scots pine seedlings, which indicates this species is moderate or weakly pathogenic, as reported previously (Jankowiak, 2012; Dori-Bachash et al., 2015).

Inoculation with $O$. ips, $O$. pallidulum, $O$. piceae and $G$. olivacea resulted in relatively small lesions indicating that these species were significantly less virulent than $O$. minus and $G$. cf. rectangulosporium. Although inoculation with $O$. ips, $O$. pallidulum and $O$. piceae resulted in significantly longer and deeper lesions compared to controls, these fungi are probably weak pathogens. In contrast to our results, $O$. ips isolated from $I$. sexdentatus in Poland causes dieback of ca. $30 \%$ of the Scots pine seedlings inoculated. Such contradictory results can probably be explained by differences in virulence of different $O$. ips isolates from Poland and Ukraine. Moreover, O. minus isolated from I. sexdentatus in Poland (Jankowiak, 2012) causes dieback of $100 \%$ of the Scots pine seedlings inoculated compared to the $45 \%$ of seedlings recorded in the present study. It appears that ophiostomatoid fungi are an important factor determining the aggressiveness of bark beetles (Krokene \& Solheim, 1998) and may account for I. acuminatus being less aggressive than I. sexdentatus. The associated fungi may play key roles in overcoming tree defence through pathogenic colonization of sapwood and phloem and facilitate the establishment of bark beetles.

\section{CONCLUSIONS}

This study revealed that $I$. acuminatus vectors a speciesrich fungal community, which is dominated by tree pathogens. This study also revealed that the community of ophiostomatoid fungi associated with $I$. acuminatus in Ukraine appears to be rather different from that reported in other regions of Europe (Guérard et al., 2000; Linnakoski, 2011; Villari et al., 2013). The association between $D$. pinea and I. acuminatus, which is reported here for the first time, is of considerable practical importance for forest health and requires further attention. Pathogenicity tests on six ophiostomatoid fungi showed that $O$. minus is the most virulent and causes dieback in seedlings of Scots pine, while other fungi tested appeared to be only slightly pathogenic or completely non-pathogenic to trees.

ACKNOWLEDGEMENTS. This study was financially supported by the Swedish Institute (SI) and also funded by the EU RTD Framework Programme COST project FP 1103, which funded the Short-Term Scientific Mission (STSM) of K. Davydenko.

\section{REFERENCES}

Altschul S.F., Gish W., Miller W., Myers E.W. \& Lipman D. J. 1990: Basic local alignment search tool. - J. Mol. Biol. 215: 403-410.

CAMARgo J. 1993: Must dominance increase with the number of subordinate species in competitive interactions? - J. Theor. Biol. 161: 537-542.

Colombari F., Battisti A., Schroeder L.M. \& Faccoli M. 2012: Life-history traits promoting outbreaks of the pine bark beetle Ips acuminatus (Coleoptera: Curculionidae, Scolytinae) in the south-eastern Alps. — Eur. J. Forest Res. 131: 553-561.

Christiansen E. \& BakKe A. 1988: The spruce bark beetle of Eurasia. In Berryman A. (ed.): Dynamics of Forest Insect Populations. Plenum, New York, pp. 480-503.

Davydenko K., Vasaitis R., Meshkova V. \& Menkis A. 2014: Fungi associated with the red-haired bark beetle, Hylurgus ligniperda (Coleoptera: Curculionidae) in the forest-steppe zone in eastern Ukraine. - Eur. J. Entomol. 111: 561-565.

De Beer Z.W. \& WingField M.J. 2013: Emerging lineages in the Ophiostomatales. In Seifert K.A., de Beer Z.W. \& Wingfield M.J. (eds): The Ophiostomatoid Fungi: Expanding Frontiers. Vol. 12. CBS, Utrecht, pp. 21-46.

De Beer Z.W., Seifert K. \& Wingfield M. 2013: A nomenclator for ophiostomatoid genera and species in the Ophiostomatales and Microascales. In Seifert K.A., de Beer Z.W. \& Wingfield M.J. (eds): The Ophiostomatoid Fungi: Expanding Frontiers. Vol. 12. CBS, Utrecht, pp. 245-322.

De Beer Z.W., Duong T.A., Barnes I., Wingfield B.D. \& WingFIELD M.J. 2014: Redefining Ceratocystis and allied genera. Studies Mycol. 79: 187-219.

Dori-Bachash M., Avrahami-Moyal L., Protasov A., Mendel Z. \& FreEmAN S. 2015: The occurrence and pathogenicity of Geosmithia spp. and common blue-stain fungi associated with pine bark beetles in planted forests in Israel. - Eur. J. Plant Pathol. 143: 627-639.

FrancKe-Grosmann H. 1952: Über die Ambrosiazucht der beiden Kiefernborkenkäfer Myelophilus minor Htg. und Ips acuminatus Gyll. - Medd. St. Skogsforskningsinst. 41: 1-52.

Francke-Grosmann H. 1963: Die Übertragung der Pilzflora bei dem Borkenkäfer Ips acuminatus Gyll.: Ein Beitrag zur Kenntnis der Ipiden-Symbiosen. - J. Appl. Entomol. 52: 355-361.

GARDES M. \& BRUNS T.D. 1993: Its primers with enhanced specificity for basidiomycetes - application to the identification of mycorrhizae and rusts. - Mol. Ecol. 2: 113-118.

Glass N.L. \& Donaldson G.C. 1995: Development of primer sets designed for use with the PCR to amplify conserved genes from filamentous ascomycetes. - Appl. Environ. Microbiol. 61: $1323-1330$

Goldazarena A., Romón P. \& López S. 2012: Bark beetles control in forests of Northern Spain. In Larramendy M.L. \& Soloneski S. (eds): Integrated Pest Management and Pest Control - Current and Future Tactics. InTech, Open Access Publisher, pp. 323-352.

Guérard N., Dreyer E. \& Lieutier F. 2000: Interactions between Scots pine, Ips acuminatus (Gyll.) and Ophiostoma brunneociliatum (Math.): Estimation of the critical thresholds of attack 
and inoculation densities and effects on hydraulic properties in the stem. - Ann. Forest Sci. 57: 681-690.

Harrington T.C. \& Wingfield M.J. 1998: The Ceratocystis species on conifers. - Can. J. Bot. 76: 1446-1457.

Jacobs K., Bergdahl D.R., Wingfield M.J., Halik S., Seifert K.A., BRIght D.E. \& Wingfield B.D. 2004: Leptographium wingfieldii introduced into North America and found associated with exotic Tomicus piniperda and native bark beetles. Mycol. Res. 108: 411-418.

JANKOWIAK R. 2006: Fungi associated with Tomicus piniperda in Poland and assessment of their virulence using Scots pine seedlings. - Ann. Forest Sci. 63: 801-808.

JANKOWIAK R. 2012: Ophiostomatoid fungi associated with Ips sexdentatus on Pinus sylvestris in Poland. - Dendrobiology 68: $43-53$.

JANKOWIAK R. 2013: Assessing the virulence of ophiostomatoid fungi associated with the pine-infesting weevils to scots pine Pinus sylvestris L. seedlings. - Acta Agrobot. 66: 85-94.

JANKOWIAK R. \& BILAŃSKI P. 2007: Fungal flora associated with Tomicus piniperda $\mathrm{L}$. in an area close to a timber yard in southern Poland. - J. Appl. Entomol. 131: 579-584.

JANKOWIAK R. \& BILANSKI P. 2013: Ophiostomatoid fungi associated with root-feeding bark beetles on Scots pine in Poland. Forest Pathol. 43: 422-428.

JANKOWIAK R. \& KolaŘíK M. 2010: Fungi associated with the fir bark beetle Cryphalus piceae in Poland. - Forest Pathol. 40: 133-144.

JANKOWIAK R., KolaŘík M. \& BilańSKi P. 2014: Association of Geosmithia fungi (Ascomycota: Hypocreales) with pine-and spruce-infesting bark beetles in Poland. - Fungal Ecol. 11: 71-79.

KAARIK A. 1975: Succession of microorganisms during wood decay. In Liese W. (ed.): Biological Transformation of Wood by Microorganisms. Proceedings of the Sessions on Wood Products Pathology at the 2nd International Congress of Plant Pathology September 10-12, 1973, Minneapolis, USA. Springer, Berlin, Heidelberg, New York, pp. 39-51.

Kim J.J., Kim S.H., LeE S. \& BReUIL C. 2003: Distinguishing Ophiostoma ips and Ophiostoma montium, two bark beetle-associated sapstain fungi. - FEMS Microbiol. Lett. 222: 187-192.

KIRISITS T. 2004: Fungal associates of European bark beetles with special emphasis on the ophiostomatoid fungi. In Lieutier F., Day K.R., Battisti A., Grégoire J.-C. \& Evans H.F. (eds): Bark and Wood Boring Insects in Living Trees in Europe, a Synthesis. Springer, Dordrecht, pp. 181-236.

KIRISITS T. 2010: Fungi isolated from Picea abies infested by the bark beetle Ips typographus in the Bialowieza forest in northeastern Poland. - Forest Pathol. 40: 100-110.

KIRISITS T. 2013: Dutch elm disease and other Ophiostoma diseases. In Gonthier P. \& Nicolotti G. (eds): Infectious Forest Diseases. CABI, Wallingford, pp. 256-282.

Klepzig K.D., Flores-Otero J., Hofstetter R.W. \& Ayres M.P. 2004: Effects of available water on growth and competition of southern pine beetle associated fungi. - Mycol. Res. 108: $183-188$.

KOLAŘ́́K M. \& JANKOWIAK R. 2013: Vector affinity and diversity of Geosmithia fungi living on subcortical insects inhabiting Pinaceae species in Central and Northeastern Europe. - Microb. Ecol. 66: 682-700.

Kolařík M., Kubátová A., Hulcr J. \& Pažoutová S. 2008: Geosmithia fungi are highly diverse and consistent bark beetle associates: evidence from their community structure in temperate Europe. - Microb. Ecol. 55: 65-80.
Krokene P. \& Solheim H. 1998: Pathogenicity of four blue-stain fungi associated with aggressive and nonaggressive bark beetles. - Phytopathology 88: 39-44.

LÀngStröm B., Solheim H., Hellqvist C. \& Gref R. 1993: Effects of pruning young Scots pines on host vigour and susceptibility to Leptographium wingfieldii and Ophiostoma minus, two blue-stain fungi associated with Tomicus piniperda. - Eur. J. Forest Pathol. 23: 400-415.

Lieutier F., Garcia J., Yart A., Vouland G., Pettinetti M. \& Morelet M. 1991: Ophiostomatales (Ascomycetes) associated with Ips acuminatus Gyll (Coleoptera, Scolytidae) in Scots Pine (Pinus sylvestris L) in South-Eastern France, and comparison with Ips sexdentatus Boern. - Agronomie 11: 807-817.

Lieutier F., Yart A. \& Salle A. 2009: Stimulation of tree defenses by Ophiostomatoid fungi can explain attack success of bark beetles on conifers. - Ann. Forest Sci. 66: 801, 22 pp.

LinNakoski R. 2011: Bark Beetle-Associated Fungi in Fennoscandia with Special Emphasis on Species of Ophiostoma and Grosmannia. Dissertationes Forestales 119. Faculty of Science and Forestry, School of Forest Sciences, University of Eastern Finland, $74 \mathrm{pp}$.

Linnakoski R., de Beer Z.W., Ahtiainen J., Sidorov E., Niemela P., Pappinen A. \& Wingfield M.J. 2010: Ophiostoma spp. associated with pine- and spruce-infesting bark beetles in Finland and Russia. - Persoonia 25: 72-93.

Linnakoski R., De Beer Z.W., Niemelä P. \& Wingfield M.J. 2012: Associations of conifer-infesting bark beetles and fungi in Fennoscandia. - Insects 3: 200-227.

Linnakoski R., Jankowiak R., Villari C., Kirisits T., Solheim H., DE BEER Z.W. \& WINGFIELD M.J. 2016: The Ophiostoma clavatum species complex: a newly defined group in the Ophiostomatales including three novel taxa. - Antonie Van Leeuwenhoek Int. J. Gener. Mol. Microbiol. 109: 987-1018.

Lu Q., Decock C., Zhang X.Y. \& Maraite H. 2009: Ophiostomatoid fungi (Ascomycota) associated with Pinus tabuliformis infested by Dendroctonus valens (Coleoptera) in northern China and an assessment of their pathogenicity on mature trees. Antonie van Leeuwenhoek Int. J. Gener. Mol. Microbiol. 96: 275-293.

Luchi N., Mancini V., Feducci M., SAntini A. \& CAPRetti P. 2012: Leptoglossus occidentalis and Diplodia pinea: a new insectfungus association in Mediterranean forests. - Forest Pathol. 42: $246-251$.

Magguran A.M. 1998: Ecological Diversity and its Measurement. Princeton University Press, Princeton, 192 pp.

Markovskaja S., Kacergius A., Davydenko K. \& Fraser S. 2016: First record of Neocatenulostroma germanicum on pines in Lithuania and Ukraine and its co-occurrence with Dothistroma spp. and other pathogens. - Forest Pathol. 46: 522-533.

MathiesEN A. 1950: Über einige Borkenkäfern assoziierte Bläuepilze in Schweden. - Oikos 2: 275-308.

Mathiesen A. 1951: Enige neue Ophiostoma-arten in Schweden. - Svensk Bot. Tidskr. 45: 203-232.

MATHIESEN-KäÄRIK A. 1953: Eine Übersicht über die gewöhnlichsten mit Borkenkäfern assoziierten Bläuepilze in Schweden und einige für Schweden neue Bläupilze. - Medd. St. Skogsforskningsinst. 43: 1-74.

Mathiesen-KäÄRIK A. 1960: Studies on the ecology, taxonomy and physiology of Swedish insect-associated blue stain fungi, especially the genus Ceratocystis. - Oikos 11: 1-25.

Mead R. \& Curnow R.N. 1983: Statistical Methods in Agriculture and Experimental Biology. Princeton University Press, Princeton, $192 \mathrm{pp}$. 
Menkis A., Vasiliauskas R., Taylor A.F.S., Stenstrom E., StenLID J. \& FinLAY R. 2006: Fungi in decayed roots of conifer seedlings in forest nurseries, afforested clear-cuts and abandoned farmland. - Plant Pathol. 55: 117-129.

Menkis A., Östbrant I.-L., Davydenko K., Bakys R., BalalaIKINS M. \& VASAITIS R. 2016: Scolytus multistriatus associated with Dutch elm disease on the island of Gotland: phenology and communities of vectored fungi. - Mycol. Progr. 15: 55, $8 \mathrm{pp}$.

ÖHRN P. 2012: The Spruce Bark Beetle Ips typographus in a Changing Climate: Effects of Weather Conditions on the Biology of Ips typographus. Swedish University of Agricultural Sciencies, Uppsala, 27 pp.

Oliva J., Boberg J. \& Stenlid J. 2013: First report of Diplodia pinea on Scots pine (Pinus sylvestris) and Austrian pine ( $P$. nigra) in Sweden. - New Dis. Rep. 27: 23.

Ohtaka N., Masuya H., Yamaoka Y. \& Kaneko S. 2006. Two new Ophiostoma species lacking conidial states isolated from bark beetles and bark beetle-infested Abies species in Japan. Botany 84: 282-293.

Persson Y., Vasaitis R., Langstrom B., Ohrn P., Ihrmark K. \& STENLID J. 2009: Fungi vectored by the bark beetle Ips typographus following hibernation under the bark of standing trees and in the forest litter. - Microb. Ecol. 58: 651-659.

Ploetz R.C., Hulcr J., Wingfield M.J. \& de Beer Z.W. 2013 Destructive tree diseases associated with ambrosia and bark beetles: black swan events in tree pathology? - Plant Dis. 97: 856-872.

RenNerfelt E. 1950: Über den Zusammenhang zwischen dem Verblauen des Holzes und den Insekten. — Oikos 2: 120-137.

Romon P., Zhou X., IturRondobeitia J.C., WingField M.J. \& GolDARAZENA A. 2007: Ophiostoma species (Ascomycetes: Ophiostomatales) associated with bark beetles (Coleoptera: Scolytinae) colonizing Pinus radiata in northern Spain. - Can. J. Microbiol. 53: 756-767.

SiItonen J. 2014: Ips acuminatus kills pines in southern Finland. — Silva Fenn. 48: 1145, 7 pp.

Simpson E.H. 1949: Measurement of diversity. — Nature 163 688.

SIX D.L. 2012: Ecological and evolutionary determinants of bark beetle - fungus symbioses. - Insects 3: 339-366.

Six D.L. \& BenTZ B.J. 2007: Temperature determines symbiont abundance in a multipartite bark beetle-fungus ectosymbiosis. - Microb. Ecol. 54: 112-118.

Six D.L. \& Wingfield M.J. 2011: The role of phytopathogenicity in bark beetle-fungus symbioses: a challenge to the classic paradigm. - Annu. Rev. Entomol. 56: 255-272.
SHANNON C.E. 1948: A mathematical theory of communication. — The Bell Syst. Tech. J. 27: 379-423.

SolHeim H. 1988: Pathogenicity of some Ips typographus-associated blue-stain fungi to Norway spruce. - Medd. Norsk Inst. Skogforsk. 40: 14, 11 pp.

Solheim H. \& KROKEne P. 1998: Growth and virulence of mountain pine beetle associated blue-stain fungi, Ophiostoma clavigerum and Ophiostoma montium. — Can. J. Bot. 76: 561-566.

Solheim H., Langstrom B. \& Hellqvist C. 1993: Pathogenicity of the blue-stain fungi Leptographium wingfieldii and Ophiostoma minus to Scots pine - effect of tree pruning and inoculum density. - Can. J. Forest Res. 23: 1438-1443.

Solheim H., KROKENE P. \& LÅngström B. 2001: Effects of growth and virulence of associated blue-stain fungi on host colonization behaviour of the pine shoot beetles Tomicus minor and $T$. piniperda. - Plant Pathol. 50: 111-116.

VILLARI C. 2012: Fungi Associated with the Pine Engraver Beetle Ips acuminatus And their Interactions with the Host Tree. PhD Thesis, University of Padova, 142 pp.

Villari C., Battisti A., Chakraborty S., Michelozzi M., BonelLO P. \& FACCOLI M. 2012: Nutritional and pathogenic fungi associated with the pine engraver beetle trigger comparable defenses in Scots pine. - TREE Physiol. 32: 867-879.

Villari C., Tomlinson J.A., Battisti A., Boonham N., Capretti P. \& FACCOLI M. 2013: Use of loop-mediated isothermal amplification for detection of Ophiostoma clavatum, the primary blue stain fungus associated with Ips acuminatus. - Appl. Environ. Microbiol. 79: 2527-2533.

WaAlberg M.E. 2015. Fungi Associated with Three Common Bark Beetle Species in Norwegian Scots Pine Forest. PhD Thesis, Norwegian University of Life Sciences, $46 \mathrm{pp}$.

White T.J., Bruns T.D., LeE S. \& TAYlor J. 1990: Amplification and direct sequencing of fungal ribosomal RNA genes for phylogenetics. In Innis M.A., Gelfand D.H., Sninsky J.J. \& White T.J. (eds): PCR Protocols: A Guide to Methods and Applications. Academic Press, New York, pp. 315-322.

WhitNey H.S., BANONI R.J. \& OBERWINKLER F. 1987: Entomocorticium dendroctoni gen. et sp. nov. (Basidiomycotina), a possible nutritional symbiote of the mountain pine beetle in lodgepole pine in British Columbia. - Can. J. Bot. 65: 95-102.

Wingfield M.J., Seifert K.A. \& Webber J.F. 1993: Ceratocystis and Ophiostoma: Taxonomy, Ecology and Pathogenicity. American Phytopathological Society Press, St. Paul, 293 pp.

Zhou X., Burgess T.I., De Beer Z.W., Lieutier F., Yart A., KlepZIG K. \& WingFIELD M.J. 2007: High intercontinental migration rates and population admixture in the sapstain fungus Ophiostoma ips. - Mol. Ecol. 16: 89-99.

Received March 15, 2016; revised and accepted December 28, 2016 Published online January 30, 2017 